\title{
Optimal Simple Targeting Rules for Small Open Economies*
}

\author{
Richard Dennis
}

Federal Reserve Bank of San Francisco

December 2000

JEL Classification: E47, E52

Key words: Inflation targeting; Optimal rules; Policy evaluation

\begin{abstract}
This paper solves for optimal policy rules in a stylized small open economy model under a spectrum of targeting regimes. These policy reaction functions are presented as feedback rules highlighting the dominant state variables in each rule. Optimal simple rules - rules that exploit a reduced information set - are explored to assess how much is lost when information is excluded from the optimal state-contingent rule. For the model analyzed we find that some optimal simple rules can approximate reasonably well the optimal state-contingent rule, these simple rules contain the real exchange rate. Knowing which variables underpin the performance of the optimal state-contingent rule is important for developing simple, robust, rules with good stabilizing properties.

* Thanks are due to Charlie Bean, Warwick McKibbin, Adrian Pagan, and Graeme Wells for helpful comments and suggestions, and to Vinita Jain for helping with the figures. Any remaining errors are mine. An earlier version of this paper appeared as an Australian National University Working Paper in Economics and Econometrics, \#362. (January, 1999).

- Address for Correspondence: Economic Research Department, Federal Reserve Bank of San Francisco, 101 Market St, San Francisco, CA 94105, USA. Email: Richard.Dennis@sf.frb.org. The views expressed in this paper do not necessarily reflect those of the Federal Reserve Bank of San Francisco or the Federal Reserve System.
\end{abstract}




\section{1) Introduction}

A growing literature explores simple policy rules as guides for monetary policy. While this literature itself is not new, what is new is the focus placed on one particular policy rule, popularly known as the Taylor rule (Taylor, 1993). In this rule a short-term nominal interest rates is set as a linear function of annual inflation and the output gap. Higher inflation leads to tighter monetary policy, and so too does higher output. The Taylor rule is very simple and intuitive, which goes some way toward explaining its popularity. But the real key to the Taylor rule's prominence comes from its ability to explain Federal Funds rate movements, post 1986.

Questions have been raised about whether policy makers could actually implement a Taylor rule to set policy. McCallum (1999) stresses that the Taylor rule is infeasible because it is based on information unavailable to policy makers when policy is set. Similarly, Orphanides (1997) shows that the predictive power of the Taylor rule depends on the data vintage used. The rule tracks the path of the Federal Funds rate well when the final data vintage is used, but not if the rule is made a function of data actually available to policy makers at the time they make their decisions. McCallum's and Orphanides' concerns aside it is becoming increasingly common to estimate Taylor type rules or to apply Taylor type rules in simulation exercises to countries other than the United States. Clarida, Gali, and Gertler (1998) estimate Taylor type rules for Japan, Germany, France, Italy, the United Kingdom, as well as the United States, Ahn (2000) estimates Taylor type rules for Australia, Nelson (2000) estimates Taylor type rules for the United Kingdom, Gerlach and Schnabel (1999) and Taylor (1999) examine Taylor type rules for the EMU, and Sanchez-Fung (2000) estimates Taylor type rules for the Dominican Republic. This list is far from complete.

Whether or not Taylor type rules are useful policy guides, it is clear that there are two issues at play. The first is whether Taylor type specifications can explain interest rate movements in a country; the second is whether such specifications are in some sense optimal, or appropriate. Regarding the first issue, any inflation targeting country is likely 
to set policy such that interest rates are above equilibrium when inflation is above target or when output is above potential output. As such we must expect Taylor type specifications to have some predictive power over interest rates in inflation targeting countries. However, in many countries, particularly small open economies, Taylor type specifications are unlikely to fully explain the systematic component of interest rates. Indeed, the studies listed above employ of range of distinct rules to explain interest rate movements, while still classifying their rule as a 'Taylor type'. Ahn (2000), for example, has specifications that include the real exchange rate, the current account, or asset prices, while Sanchez-Fung's (2000) Taylor type rule has base money as the instrument with policy responding (directly) to exchange rates, but not inflation.

Turning to the issue of whether Taylor type rules are in some sense optimal or appropriate, Rudebusch and Svensson (1999) showed that for the United States the performance of Taylor type rules closely approximates that of the optimal statecontingent rule. Intuitively, if the policy objective is to stabilize the output gap and inflation about some target, then the key to success is to be able to forecast these two variables, and then base policy around those variables that best help these forecasts. In Rudebusch and Svensson's (1999) model the output gap and inflation are explained by lags of the output gap and inflation, and the output gap and inflation are of course also the defining variables in a Taylor type rule. But in small open economies, as many inflation targeting countries are, we might expect variables other than inflation and the output gap to be important for setting policy, as the Monetary Conditions Indicator literature emphasizes. Monetary Conditions Indicators are based on the very idea that in small open economies the size of the tradeable goods sector makes the exchange rate an important conditioning variable for monetary policy.

This paper employs a small open economy model and explores the question of how to construct high performance simple rules. Unlike a large part of the monetary policy rules literature we do not determine a rule's success by the performance of other simple rules. Rather, we gauge a simple rule's success against the performance of the optimal statecontingent rule. We are interested in uncovering those variables that are important to 
policy's success in small open economies, and whether the simple rules that do perform well look similar to Taylor rules. Throughout this paper we heed McCallum's (1999) criticism and undertake our analysis in terms of feasible rules. Consequently, for this paper we define Taylor's rule to be that with the specific coefficients 0.5 and 1.5 applied to the lagged output gap and lagged annual inflation respectively, and a Taylor type rule as one where these two coefficients are arbitrary. For both Taylor's rule and Taylor type rules the nominal interest rate is set as a linear function of just annual inflation and the output gap. ${ }^{1}$

We begin in section 2 by introducing and discussing the properties of the model underpinning our analysis. In many ways this model can be viewed as a discrete time version of the Buiter and Miller (1981) model. Buiter and Miller's (1981) model is in turn an extension of Dornbusch's (1976) seminal sticky price exchange rate model. Section 3 considers the stabilizing properties of optimal inflation targeting rules for two model specifications. The first has all agents backward-looking; the second has all agents forward-looking and rational to some extent.

Optimal simple rules are discussed and analyzed in section 4 where it is found that rules based on only three particular state variables can indeed well approximate the optimal state-contingent rule. Among these important state variables is the real exchange rate. Section 5 offers concluding comments.

\section{2) A Small Open Economy Model}

The model considered has its origins in Dornbusch (1976) and Buiter and Miller (1981). Its structure is:

\footnotetext{
${ }^{1}$ All variables in the economy are defined as deviations from steady-states so intercepts are unimportant.
} 


\section{1) Domestic Economy ${ }^{2}$}

$$
\begin{array}{ll}
\mathrm{y}_{\mathrm{t}}=\lambda \mathrm{y}_{\mathrm{t}-1}-\gamma\left[\mathrm{i}_{\mathrm{t}}-\pi_{\mathrm{t}}^{\mathrm{e}, \mathrm{c}}\right]+\mu \mathrm{q}_{\mathrm{t}-1}+\theta \mathrm{y}_{\mathrm{t}-1}^{\mathrm{f}}+\mathrm{v}_{\mathrm{t}} & \gamma, \mu, \theta>0,0 \leq \lambda<1 \\
\pi_{\mathrm{t}}^{\mathrm{e}, \mathrm{c}} \equiv \delta \mathrm{E}_{\mathrm{t}-1} \pi_{\mathrm{t}+1}^{\mathrm{c}}+(1-\delta) \pi_{\mathrm{t}-1}^{\mathrm{c}} & 0 \leq \delta \leq 1 \\
\pi_{\mathrm{t}}=\rho \mathrm{E}_{\mathrm{t}-1} \pi_{\mathrm{t}+1}+(1-\rho) \pi_{\mathrm{t}-1}+\alpha \mathrm{y}_{\mathrm{t}-1}+\mathrm{u}_{\mathrm{t}} & \alpha>0,0 \leq \rho \leq 1 \\
\pi_{\mathrm{t}}^{\mathrm{c}}=\kappa \pi_{\mathrm{t}}^{\mathrm{i}}+(1-\kappa) \pi_{\mathrm{t}} & \\
\mathrm{p}_{\mathrm{t}}^{\mathrm{i}}=\mathrm{e}_{\mathrm{t}}+\mathrm{p}_{\mathrm{t}}^{\mathrm{f}} & \\
\mathrm{e}_{\mathrm{t}}=\delta \mathrm{E}_{\mathrm{t}-1} \mathrm{e}_{\mathrm{t}+1}+(1-\delta) \mathrm{e}_{\mathrm{t}-1}+\mathrm{i}_{\mathrm{t}}^{\mathrm{f}}-\mathrm{i}_{\mathrm{t}}+\varepsilon_{\mathrm{t}} & \\
\mathrm{q}_{\mathrm{t}}=\mathrm{e}_{\mathrm{t}}+\mathrm{p}_{\mathrm{t}}^{\mathrm{f}}-\mathrm{p}_{\mathrm{t}}^{\mathrm{c}} &
\end{array}
$$

$$
\text { Where: } \quad \begin{aligned}
\mathrm{y}_{\mathrm{t}} & =\text { domestic output gap } \\
\pi_{\mathrm{t}} & =\text { nontradeables inflation rate } \\
\pi_{\mathrm{t}}^{\mathrm{c}} & =\text { consumer price inflation rate } \\
\pi_{\mathrm{t}}^{\mathrm{i}} & =\text { import price inflation } \\
\mathrm{p}_{\mathrm{t}}^{\mathrm{i}} & =\text { import price level (in domestic dollars) } \\
\mathrm{p}_{\mathrm{t}}^{\mathrm{c}} & =\text { consumer price level } \\
\mathrm{p}_{\mathrm{t}}{ }^{\mathrm{f}} & =\text { foreign price level } \\
\mathrm{i}_{\mathrm{t}} & =\text { domestic nominal interest rate } \\
\mathrm{i}_{\mathrm{t}}^{\mathrm{f}} & =\text { foreign nominal interest rate } \\
\mathrm{q}_{\mathrm{t}} & =\text { real exchange rate } \\
\mathrm{y}_{\mathrm{t}}^{\mathrm{f}} & =\text { foreign output gap } \\
\mathrm{e}_{\mathrm{t}} & =\text { effective nominal exchange rate } \\
\mathrm{v}_{\mathrm{t}} & =\text { domestic demand shock } \\
\mathrm{u}_{\mathrm{t}} & =\text { domestic supply shock } \\
\varepsilon_{\mathrm{t}} & =\text { portfolio preference shock. }
\end{aligned}
$$

\footnotetext{
${ }^{2}$ Throughout this paper the domestic economy will be associated with the small open economy and the foreign economy with the large economy.
} 


\section{2) Foreign Economy}

$$
\begin{array}{ll}
\mathrm{y}_{\mathrm{t}}^{\mathrm{f}}=\lambda^{\mathrm{f}} \mathrm{y}_{\mathrm{t}-1}^{\mathrm{f}}-\gamma^{\mathrm{f}}\left[\mathrm{i}_{\mathrm{t}}^{\mathrm{f}}-\pi_{\mathrm{t}}^{\mathrm{e}, \mathrm{f}}\right]+\mathrm{v}_{\mathrm{t}}^{\mathrm{f}} & \gamma^{\mathrm{f}}>0,0 \leq \lambda^{\mathrm{f}}<1 \\
\pi_{\mathrm{t}}^{\mathrm{e}, \mathrm{f}} \equiv \tau \mathrm{E}_{\mathrm{t}-1} \pi_{\mathrm{t}+1}^{\mathrm{f}}+(1-\tau) \pi_{\mathrm{t}-1}^{\mathrm{f}} & 0 \leq \tau \leq 1 \\
\pi_{\mathrm{t}}^{\mathrm{f}}=\omega \mathrm{E}_{\mathrm{t}-1} \pi_{\mathrm{t}+1}^{\mathrm{f}}+(1-\omega) \pi_{\mathrm{t}-1}+\alpha^{\mathrm{f}} \mathrm{y}_{\mathrm{t}-1}^{\mathrm{f}}+\mathrm{u}_{\mathrm{t}}^{\mathrm{f}} & \alpha^{\mathrm{f}}>0,0 \leq \omega \leq 1 \\
\mathrm{i}_{\mathrm{t}}^{\mathrm{f}}=\varphi_{1}^{\mathrm{f}} \mathrm{y}_{\mathrm{t}-1}^{\mathrm{f}}+\varphi_{2}^{\mathrm{f}} \pi_{\mathrm{t}-1}^{\mathrm{f}} &
\end{array}
$$

$$
\text { Where: } \quad \begin{array}{ll}
\pi_{\mathrm{t}}^{\mathrm{f}} & =\text { foreign inflation rate } \\
\mathrm{v}_{\mathrm{t}}{ }^{\mathrm{f}} & =\text { foreign demand shock } \\
\mathrm{u}_{\mathrm{t}}{ }^{\mathrm{f}} & =\text { foreign supply shock. }
\end{array}
$$

Aside from interest rates and inflation rates, all variables are interpreted in logs, and all price levels are linked to inflation rates through the standard identity.

Equation (1) is a dynamic IS curve expressed in interest rate/output gap space, but where the curve is conditioned upon the real exchange rate, $\mathrm{q}_{\mathrm{t}-1}$, and the foreign output gap, $\mathrm{y}_{\mathrm{t}-1}^{\mathrm{f}}$, to reflect the openness of the economy. Nontradeables' inflation is driven by a Phillips curve with mixed inflation expectations, equation (3). This mixed inflation expectations structure encompasses a number of different wage and price setting models; more will be said about this below. We note in passing, however, that this Phillips curve omits any direct exchange rate effect. This is a feature of the Buiter-Miller model. Consumer price inflation, equation (4), is a weighted average of imported goods price inflation and nontradeables inflation, where the weight on imported goods inflation is the direct exchange rate pass-through coefficient. ${ }^{3}$ Equation (5) defines import prices in term of foreign prices and the nominal exchange rate. The nominal exchange rate, $e_{t}$, represents the number of domestic dollars it takes to purchase one foreign dollar.

\footnotetext{
${ }^{3}$ This direct exchange rate pass-through coefficient is a partial elasticity. In the long-run a $1 \%$ permanent depreciation of the nominal exchange rate will cause both domestic prices and consumer prices to rise by $1 \%$.
} 
We model the nominal exchange rate using (6), which is simply an uncovered interest parity (UIP) condition, but with mixed expectations as per equation (2). This UIP condition simply states that the expected change in the exchange rate fully offsets the foreign-domestic nominal interest rate differential. The real exchange rate is defined in terms of consumer prices rather than the nontradeable output price. However, these two measures of the real exchange rate are related. If we denote $\mathrm{q}_{\mathrm{t}}{ }^{\mathrm{d}}$ as the real exchange rate in terms of domestic goods prices, then $q_{t}=(1-\kappa) q_{t}{ }^{d}$. Consequently, either real exchange rate measure can be used in practice. Throughout we define our real exchange rate in terms of consumer prices and to keep things consistent we also define our real interest rate in terms of consumer price inflation. The inflation expectation present in the Phillips curve relates to nontradeable goods prices. ${ }^{4}$

The mixed inflation expectations formulation used can be derived or motivated in a number of ways. Ball (1999b) has a model in which $\rho$ equals zero. In Ball's model the uncontrolled inflation equation contains a unit root, which is motivated by the large degree of persistence observed in actual inflation rates. Taylor (1980), on the other hand, derives a Phillips curve based on over-lapping nominal wage contracts in which $\rho$ equals one and inflation expectations are purely forward-looking. The weakness with Taylor's contracting specification is that it makes domestic inflation a jump variable, making it difficult to replicate the persistence found in actual inflation series. Between these two extremes lies a version of Fuhrer and Moore's (1995) over-lapping relative real wage contracting model in which $\rho=0.5$. The mixed expectations formulation encompasses these three specifications, among others.

Mixed expectations process are also contained in equations (2) and (6), where the mixing parameter $\delta$ is constrained to be the same across the two equations. The intent behind the mixed expectations process here is simply to allow us to capture features found in data based models. Models in which $\delta=1$ are common because they are implied by

\footnotetext{
${ }^{4}$ Svensson (1998) in his study of open economy inflation targeting takes the alternative approach of defining the real exchange using domestic goods prices and then also using expected domestic goods inflation when defining the real interest rate.
} 
rationality and efficient market considerations. Similarly, it is not unusual for models in which the UIP equation is estimated to have $\delta$ either 0 or close to 0 (Beechey et al, 2000). In what follows we only consider specifications in which $\delta$ equals either 0 or 1.

The foreign sector is of the same genre used by Svensson (1997) and Ball (1999a), and aside from the absence of a tradeable goods sector it has a similar structure to the domestic economy. In addition the foreign sector has an explicit foreign policy reaction function, equation (11). Unlike Svensson (1998), here the foreign policy reaction function is determined through optimization.

Taken together there is a recursive structure to the two economies. Events occurring in the foreign economy have implications for the domestic economy, but not vice versa. This causality reflects the 'smallness' of the domestic economy and the 'largeness' of the foreign economy. The recursive structure allows us to solve the foreign policy makers' policy optimization problem first and then condition on that solution when solving the domestic policy makers' policy optimization problem.

To reduce the dimensions of the system we exploit the real exchange rate's definition and write the UIP equation in real terms.

$\mathrm{q}_{\mathrm{t}}=\mathrm{q}_{\mathrm{t}+1}^{\mathrm{e}}+\left[\mathrm{i}_{\mathrm{t}}^{\mathrm{f}}-\pi_{\mathrm{t}+1}^{\mathrm{e}, \mathrm{f}}\right]-\left[\mathrm{i}_{\mathrm{t}}-\pi_{\mathrm{t}+1}^{\mathrm{e}, \mathrm{c}}\right]+\varepsilon_{\mathrm{t}}$.

Substituting (7) into (5) gives

$\mathrm{p}_{\mathrm{t}}^{\mathrm{i}}=\mathrm{q}_{\mathrm{t}}+\mathrm{p}_{\mathrm{t}}^{\mathrm{c}}$,

which when differenced produces

$\pi_{\mathrm{t}}^{\mathrm{i}}=\Delta \mathrm{q}_{\mathrm{t}}+\pi_{\mathrm{t}}^{\mathrm{c}}$ 
Import price inflation, from equation (14), can now be substituted into the definition of consumer price inflation, equation (4), resulting in

$$
\pi_{\mathrm{t}}^{\mathrm{c}}=\frac{\kappa}{1-\kappa} \Delta \mathrm{q}_{\mathrm{t}}+\pi_{\mathrm{t}} .
$$

This simplified model, which excludes the levels of all nominal variables, contains just seven endogenous variables, of which only five are stochastic endogenous. The entire system is:

$$
\begin{aligned}
& \mathrm{y}_{\mathrm{t}}=\lambda \mathrm{y}_{\mathrm{t}-1}-\gamma\left[\mathrm{i}_{\mathrm{t}}-\delta \mathrm{E}_{\mathrm{t}-1} \pi_{\mathrm{t}+1}^{\mathrm{c}}-(1-\delta) \pi_{\mathrm{t}-1}^{\mathrm{c}}\right]+\mu \mathrm{q}_{\mathrm{t}-1}+\theta \mathrm{y}_{\mathrm{t}-1}^{\mathrm{f}}+\mathrm{v}_{\mathrm{t}} \\
& \pi_{\mathrm{t}}=\rho \mathrm{E}_{\mathrm{t}-1} \pi_{\mathrm{t}+1}+(1-\rho) \pi_{\mathrm{t}-1}+\alpha \mathrm{y}_{\mathrm{t}-1}+\mathrm{u}_{\mathrm{t}} \\
& \pi_{\mathrm{t}}^{\mathrm{c}}=\frac{\kappa}{1-\kappa} \Delta \mathrm{q}_{\mathrm{t}}+\pi_{\mathrm{t}} \\
& \mathrm{q}_{\mathrm{t}}=\delta \mathrm{E}_{\mathrm{t}-1} \mathrm{q}_{\mathrm{t}+1}+(1-\delta) \mathrm{q}_{\mathrm{t}-1}+\left[\mathrm{i}_{\mathrm{t}}^{\mathrm{f}}-\tau \mathrm{E}_{\mathrm{t}-1} \pi_{\mathrm{t}+1}^{\mathrm{f}}-(1-\tau) \pi_{\mathrm{t}-1}^{\mathrm{f}}\right]-\left[\mathrm{i}_{\mathrm{t}}-\delta \mathrm{E}_{\mathrm{t}-1} \pi_{\mathrm{t}+1}^{\mathrm{c}}-(1-\delta) \pi_{\mathrm{t}-1}^{\mathrm{c}}\right]+\varepsilon_{\mathrm{t}}
\end{aligned}
$$

$$
\begin{aligned}
& \mathrm{y}_{\mathrm{t}}^{\mathrm{f}}=\lambda^{\mathrm{f}} \mathrm{y}_{\mathrm{t}-1}^{\mathrm{f}}-\gamma^{\mathrm{f}}\left[\mathrm{i}_{\mathrm{t}}^{\mathrm{f}}-\tau \mathrm{E}_{\mathrm{t}-1} \pi_{\mathrm{t}+1}^{\mathrm{f}}-(1-\tau) \pi_{\mathrm{t}-1}^{\mathrm{f}}\right]+\mathrm{v}_{\mathrm{t}}^{\mathrm{f}} \\
& \pi_{\mathrm{t}}^{\mathrm{f}}=\omega \mathrm{E}_{\mathrm{t}-1} \pi_{\mathrm{t}+1}^{\mathrm{f}}+(1-\omega) \pi_{\mathrm{t}-1}^{\mathrm{f}}+\alpha^{\mathrm{f}} \mathrm{y}_{\mathrm{t}-1}^{\mathrm{f}}+\mathrm{u}_{\mathrm{t}}^{\mathrm{f}} \\
& \mathrm{i}_{\mathrm{t}}^{\mathrm{f}}=\varphi_{1}^{\mathrm{f}} \mathrm{y}_{\mathrm{t}-1}^{\mathrm{f}}+\varphi_{2}^{\mathrm{f}} \pi_{\mathrm{t}-1}^{\mathrm{f}}
\end{aligned}
$$

Events occur as follows. At the end of period $\mathrm{t}-1$ all $\mathrm{t}-1$ variables are realized. Then, during period t, policy makers set the level of their instrument and expectations are formed. After policy is set and expectations are formed shocks occur and period t variables are realized. With this timing of events and lag structure the model is best thought of as an annual one with policy set and expectations formed on the basis of period t-1 information and the ex ante distributions of the shocks.

Two model specifications are considered, which vary in how expectations are formed. These models have not been estimated or formally calibrated to any specific economy's data. An advantage of this is that the results produced are not specific to any one 
country. Following Svensson (1998) the aim has been to set values for $\alpha, \gamma, \delta$, etc that are not obviously contrary with those we might expect to find if the model were estimated. To this end, the system's structure and its parameters have been chosen to reflect features of estimated models.

Considering the foreign economy first, we set $\lambda^{f}=0.9$ and $\gamma^{f}=0.8$ in the dynamic IS curve. In the Phillips curve we set $\alpha^{\mathrm{f}}=0.4$. We choose $\varphi_{1}^{\mathrm{f}}$ and $\varphi_{2}^{\mathrm{f}}$ according to an optimization procedure. The foreign central bank sets $\varphi_{1}^{\mathrm{f}}$ and $\varphi_{2}^{\mathrm{f}}$ to minimize the objective function: ${ }^{5}$

$\operatorname{Loss}^{\mathrm{f}}[0, \infty]=\left(1-\beta^{\mathrm{f}}\right) \operatorname{Var}\left(\mathrm{y}_{\mathrm{t}}^{\mathrm{f}}\right)+\beta^{\mathrm{f}} \operatorname{Var}\left(\pi_{\mathrm{t}}^{\mathrm{f}}\right)$

with $\beta^{\mathrm{f}}=0.5$.

The parameters in the domestic economy are set in symmetry with the foreign economy. ${ }^{6}$ That is $\alpha=0.4$ in the Phillips curve, $\lambda=0.9$ and $\gamma=0.8$ in the dynamic IS curve. To complete the IS curve's specification we set $\mu=0.4$, and $\theta=0.1$. This value for $\mu$ implies that the IS curve has a Monetary Conditions Ratio $(\gamma / \mu)$ of 2. A typical estimate of the Monetary Conditions Ratio for a small open economy ${ }^{7}$ is between 1.5 and 3.5. Our ratio is comfortably within this range. The direct exchange rate pass-through coefficient, $\kappa$, is set equal to 0.3 , indicating that exchange rate influenced prices take a $30 \%$ weighting in the consumers' price index. Like Svensson (1998) the stochastic

\footnotetext{
${ }^{5}$ This loss function, as well as that presented later for the domestic monetary authority, is in terms of the variances of variables, which assumes that variable averages are being targeted. Ball (1999a,b), Fair and Howrey (1996), Rudebusch and Svensson (1999) and numerous other papers also take this approach, which leaves the question of what the optimal levels to target is unanswered (see Pagan, 1997). Note that this form of the objective function can be derived from a discounted quadratic function in the limiting case where the discount factor approaches unity.

${ }^{6}$ An advantage of assuming symmetry here is that it makes clear that the differing results between the domestic and foreign sectors are due to the small open economy nature of the domestic economy and not due to asymmetry brought about by coefficient differences.

${ }^{7}$ See Duguay (1994), Gerlach and Smets (2001), and Eika, Ericsson, and Nymoen (1996) for typical MCR estimates for small open economies.
} 
specification of the system is completed by setting $\sigma_{\mathrm{u}}=\sigma_{\mathrm{v}}=\sigma_{\varepsilon}=\sigma_{\mathrm{u}}{ }^{\mathrm{f}}=\sigma_{\mathrm{v}}{ }^{\mathrm{f}}=1$, and all covariance terms to zero.

The two model specifications we consider differ in how expectations are formed. The first model - Model A - has all expectations backward-looking. That is $\delta=\rho=\tau=\omega=0$ and all agents simply take last period's value of a variable as their expectation of its next period value. The Phillips curves in the two economies are accelerationist, like Ball (1999b). The second model - Model B - introduces forward-looking rational behavior. Agents operating in financial markets are taken to be fully forward-looking and rational $(\delta=\tau=1)$ while agents operating in factor markets form mixed expectations $(\rho=\omega=$ 0.5). In Model B the Phillips curve has a form similar to a Fuhrer-Moore over-lapping wage contracting model, making the change in inflation and not the inflation rate itself a jump variable. Consequently, inflation is still persistent.

\section{3) Optimal State-Contingent Rules}

For the domestic economy, consider the objective function

$$
\operatorname{Loss}[0, \infty]=(1-\beta) \operatorname{Var}\left(y_{t}\right)+\beta \operatorname{Var}\left(\pi_{t}^{*}\right)
$$

where because policy makers can target either consumer price inflation or nontradeables inflation $\pi_{\mathrm{t}}^{*}$ can be either $\pi_{\mathrm{t}}$ or $\pi_{\mathrm{t}}^{\mathrm{c}}$. The parameter $\beta$ describes the policy preferences of the monetary authority and it dictates the extent to which policy makers 'lean against the wind' or accommodate supply shocks. Following Svensson (1998), when $\beta=1$ the policy regime is referred to as Strict Inflation Targeting (SIT); when $\beta=0.5$ the regime is called Flexible Inflation Targeting (FIT). For a given value of $\beta$ the domestic monetary authority minimizes equation (24) subject to the dynamic constraints imposed by the structure of the economy - either Model A or Model B. The method used to solve for these optimal policy rules is described in Dennis (2000). 


\section{1) Model A}

Recall that in Model A all agents are assumed to be naïve and backward-looking; the parameters $\delta, \rho, \tau$, and $\omega$ are all set to zero. The monetary authority bases its current policy decisions on the observed state variables: $\mathrm{y}_{\mathrm{t}-1} ; \pi_{\mathrm{t}-1} ; \pi_{\mathrm{t}-1}^{\mathrm{c}} ; \mathrm{q}_{\mathrm{t}-1} ; \mathrm{y}_{\mathrm{t}-1}^{\mathrm{f}}$; and $\pi_{\mathrm{t}-1}^{\mathrm{f}}$. Recall also that the foreign policy reaction function is determined by minimizing equation (23) with $\beta^{\mathrm{f}}=0.5$. Table 1 presents summary simulation results in the form of unconditional variances for optimal policy rules, under a selection of policy regimes. The associated optimal policy rules themselves are presented in Table 2.

\begin{tabular}{|c|c|c|c|c|c|c|c|c|c|}
\hline \multicolumn{7}{|c|}{ Table 1: Unconditional Variances for Model A } \\
\hline Regime & $\beta$ & $\operatorname{Var}\left(\mathrm{y}_{\mathrm{t}}\right)$ & $\operatorname{Var}\left(\pi_{\mathrm{t}}\right)$ & $\operatorname{Var}\left(\pi_{\mathrm{t}}^{\mathrm{c}}\right)$ & $\operatorname{Var}\left(\mathrm{q}_{\mathrm{t}}\right)$ & $\operatorname{Var}\left(\mathrm{i}_{\mathrm{t}}\right)$ & $\operatorname{Var}\left(\mathrm{y}_{\mathrm{t}}^{\mathrm{f}}\right)$ & $\operatorname{Var}\left(\pi_{\mathrm{t}}^{\mathrm{f}}\right)$ & $\operatorname{Var}\left(\mathrm{i}_{\mathrm{t}}^{\mathrm{f}}\right)$ \\
\hline $\operatorname{FIT}\left(\pi_{\mathrm{t}}\right)$ & 0.5 & 2.42 & 3.12 & 4.51 & 9.15 & 12.04 & 2.42 & 3.12 & 7.70 \\
$\operatorname{SIT}\left(\pi_{\mathrm{t}}\right)$ & 1.0 & 8.25 & 2.16 & 7.12 & 22.56 & 63.90 & 2.42 & 3.12 & 7.70 \\
$\operatorname{FIT}\left(\pi_{\mathrm{t}}^{\mathrm{c}}\right)$ & 0.5 & 2.52 & 3.21 & 4.15 & 8.55 & 8.02 & 2.42 & 3.12 & 7.70 \\
$\operatorname{SIT}\left(\pi_{\mathrm{t}}^{\mathrm{c}}\right)$ & 1.0 & 8.80 & 3.29 & 3.02 & 18.31 & 11.67 & 2.42 & 3.12 & 7.70 \\
\hline
\end{tabular}

Table 1 shows how the variances of the eight variables in the system are affected by the particular policy reaction function used by policy makers. For the foreign economy the same policy reaction function is used throughout and the smallness of the domestic economy prevents domestic policy decisions from affecting the foreign economy. Consequently the volatility of variables in the foreign economy are invariant to the domestic policy regime. For the domestic economy, unsurprisingly, SIT - for either nontradeables inflation or consumer price inflation - leads to greater variances for output and the real exchange rate than FIT. For each value of $\beta$ considered targeting $\pi_{t}{ }^{c}$ rather than $\pi_{\mathrm{t}}$ leads to less volatility in the real exchange rate and the domestic nominal interest rate. Intuitively this result occurs because dampening that variance of consumers' price inflation requires dampening the variance of imported goods inflation. A volatile nominal interest rate generates a volatile nominal exchange rate, which given the sluggish price adjustment present in the model translates into increased variances for the real exchange rate and imported goods prices. 
Interestingly, in the case where the domestic economy has a Flexible Inflation Target on domestic inflation, the variances of domestic inflation and the output gap are the same in the domestic and foreign economies. The reason for this becomes clear upon examining the domestic policy reaction function: domestic policy acts to neutralize the effects of foreign shocks on output and domestic inflation. That the domestic economy is still importing volatility from abroad is apparent in the interest rate's variability, which is larger for the domestic economy.

\begin{tabular}{|c|c|c|c|c|c|c|c|}
\hline \multicolumn{7}{|c|}{ Table 2: Optimal Policy Rules for Model A } \\
\hline Regime & $\beta$ & $\mathrm{y}_{\mathrm{t}-1}$ & $\pi_{\mathrm{t}-1}$ & $\pi_{\mathrm{t}-1}^{\mathrm{c}}$ & $\mathrm{q}_{\mathrm{t}-1}$ & $\mathrm{y}_{\mathrm{t}-1}^{\mathrm{f}}$ & $\pi_{\mathrm{t}-1}^{\mathrm{f}}$ \\
\hline $\operatorname{FIT}\left(\pi_{\mathrm{t}}\right)$ & 0.5 & 1.535 & 1.025 & 1.000 & 0.500 & 0.125 & 0.000 \\
$\operatorname{SIT}\left(\pi_{\mathrm{t}}\right)$ & 1.0 & 2.375 & 3.125 & 1.000 & 0.500 & 0.125 & 0.000 \\
$\operatorname{FIT}\left(\pi_{\mathrm{t}}^{\mathrm{c}}\right)$ & 0.5 & 1.307 & 0.883 & 1.000 & 0.433 & 0.347 & 0.173 \\
$\operatorname{SIT}\left(\pi_{\mathrm{t}}^{\mathrm{c}}\right)$ & 1.0 & 1.206 & 1.565 & 1.000 & 0.293 & 0.822 & 0.530 \\
\hline
\end{tabular}

Table 2 shows the policy reaction functions associated with each of the policy regimes considered in Table 1. Rows one and two reveal that when domestic inflation is targeted monetary policy responds similarly to foreign variables and the real exchange rate regardless of the policy preference parameter $\beta$. This occurs because foreign variables and the real exchange rate affect nontradeables inflation only through their influence on excess demand. By setting these coefficients to offset foreign demand and supply shocks policy makers can then concentrate on minimizing the effects of domestic shocks on output and domestic inflation. Clearly, none of the rules in Table 2 resembles a Taylor type rule, because variables other than the output gap and inflation appear non-trivially in the optimal state-contingent rule. 


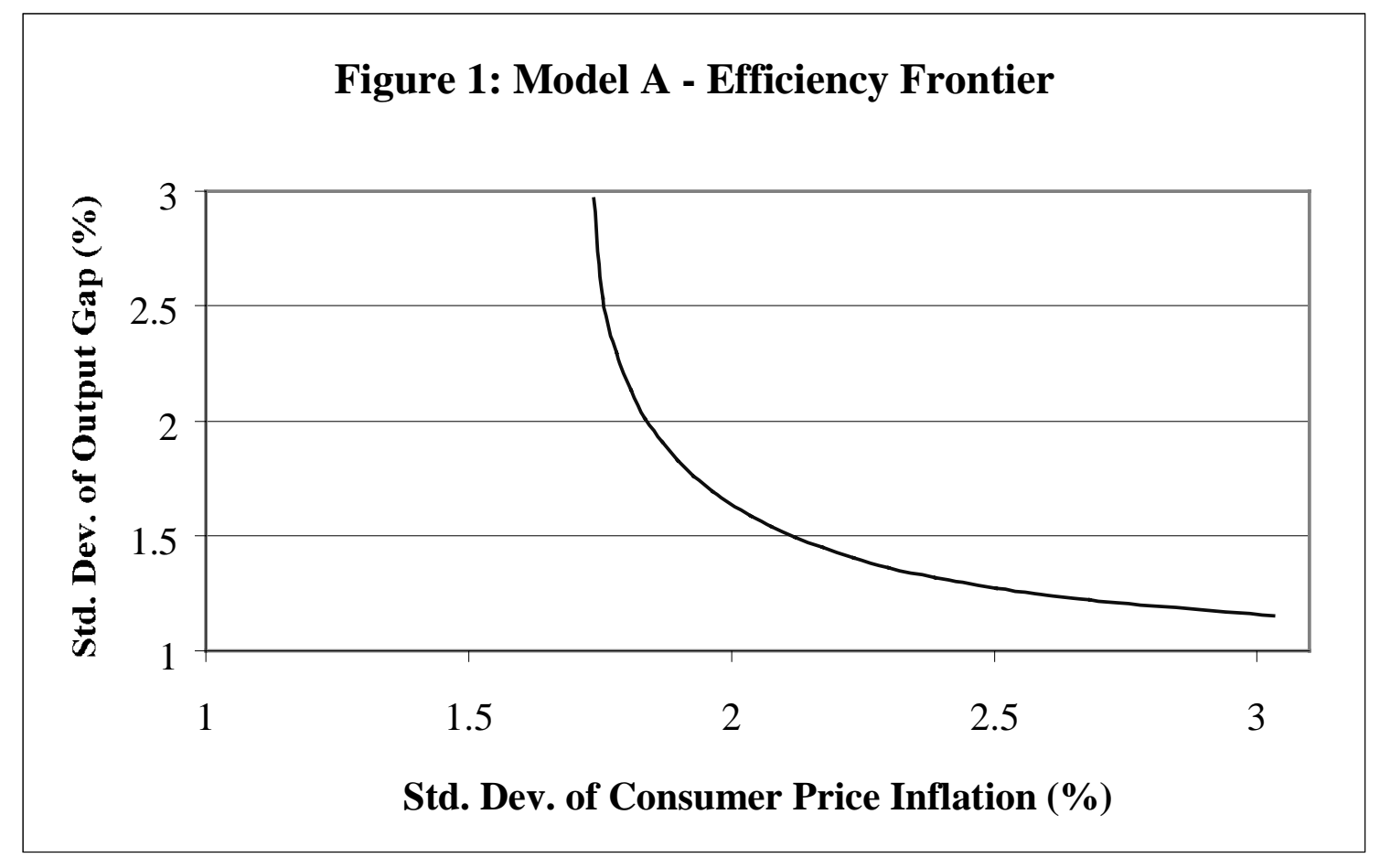

The efficiency frontier for Model A, which traces out the volatility trade-off between the output gap and consumer price inflation as $\beta$ varies, is plotted in Figure 1. This figure reveals the model's efficiency frontier to have the standard rectangular hyperbola shape. Only when the monetary authority clamps down hard on inflation's variance, as it does under SIT, does the reduced variance of inflation translate into a large increase in the variance of the output gap.

\section{2) Model B}

Unlike Model A, in which agents do not form rational expectations, Model B assumes that financial markets are rational and forward-looking $(\delta=\tau=1)$. In other markets agents are assumed to form mixed expectations, their expectations are partly forwardlooking and partly backward-looking $(\rho=\omega=0.5)$. Because financial market expectations are now forward-looking $\pi_{\mathrm{t}-1}^{\mathrm{c}}$ is no longer a state variable in the system. The set of observed state variables is: $\mathrm{y}_{\mathrm{t}-1} ; \pi_{\mathrm{t}-1} ; \mathrm{q}_{\mathrm{t}-1} ; \mathrm{y}_{\mathrm{t}-1}^{\mathrm{f}} ;$ and $\pi_{\mathrm{t}-1}^{\mathrm{f}}$. 
With forward-looking agents in the model the optimal discretionary rule and the optimal pre-commitment rule no longer coincide. ${ }^{8}$ The results of this section are generated assuming pre-commitment. ${ }^{9}$ Pre-commitment can be achieved by either an optimal contracting arrangement between the government and the governor (Walsh, 1995) or through reputation effects (Barro and Gordon, 1983). Under pre-commitment policy makers find the cost of stabilizing inflation, in terms of output's variance, lower than under discretion. Consequently, inflation's variance when there is pre-commitment to a rule is lower than that achieved under policy discretion (see Clarida, Gali, and Gertler, 1999).

All of the variances in Table 3 are smaller than their counterparts in Table 1. With forward-looking agents and the knowledge that the monetary authority is committed to its policy announcements the economy becomes easier to stabilize. Differences between Models A and B show up particularly in the variances of the real exchange rate and the domestic nominal interest rate, indicating the less activist role monetary policy plays in stabilizing the economy when agents are forward-looking.

\begin{tabular}{|l|c|c|c|c|c|c|c|c|c|}
\hline \multicolumn{10}{|c|}{ Table 3: Unconditional Variances for Model B } \\
\hline Regime & $\beta$ & $\operatorname{Var}\left(\mathrm{y}_{\mathrm{t}}\right)$ & $\operatorname{Var}\left(\pi_{\mathrm{t}}\right)$ & $\operatorname{Var}\left(\pi_{\mathrm{t}}^{\mathrm{c}}\right)$ & $\operatorname{Var}\left(\mathrm{q}_{\mathrm{t}}\right)$ & $\operatorname{Var}\left(\mathrm{i}_{\mathrm{t}}\right)$ & $\operatorname{Var}\left(\mathrm{y}_{\mathrm{t}}^{\mathrm{f}}\right)$ & $\operatorname{Var}\left(\pi_{\mathrm{t}}^{\mathrm{f}}\right)$ & $\operatorname{Var}\left(\mathrm{i}_{\mathrm{t}}^{\mathrm{f}}\right)$ \\
\hline $\operatorname{FIT}\left(\pi_{\mathrm{t}}\right)$ & 0.5 & 1.27 & 1.57 & 3.17 & 3.52 & 7.84 & 1.27 & 1.57 & 3.01 \\
$\operatorname{SIT}\left(\pi_{\mathrm{t}}\right)$ & 1.0 & 2.80 & 1.33 & 4.18 & 6.38 & 26.21 & 1.27 & 1.57 & 3.01 \\
$\operatorname{FIT}\left(\pi_{\mathrm{t}}^{\mathrm{c}}\right)$ & 0.5 & 1.29 & 1.67 & 2.97 & 3.07 & 5.15 & 1.27 & 1.57 & 3.01 \\
$\operatorname{SIT}\left(\pi_{\mathrm{t}}^{\mathrm{c}}\right)$ & 1.0 & 2.19 & 1.65 & 2.74 & 3.42 & 5.76 & 1.27 & 1.57 & 3.01 \\
\hline
\end{tabular}

\footnotetext{
${ }^{8}$ The policy objective function used throughout this study directs the monetary authority to target potential output - not some rate of output above potential. As a consequence the difference between the optimal commitment and discretionary rules does not manifest itself in the form of an inflation bias. However, the time inconsistency does alter the trade-off between the variances of output and inflation facing the monetary authority, which changes the shape of the efficiency frontier.

${ }^{9}$ Assuming commitment has the advantage that the simulation results presented can be easily be compared with studies exploring the performance of simple rules, which implicitly assume the existence of some pre-commitment technology.
} 
As earlier under nontradeables inflation targeting the domestic policy aims to neutralize foreign shocks from affecting output and nontradeables inflation, but foreign shocks are still reflected in higher interest rate volatility. Table 4 presents the policy reaction functions associated with each of the targeting regimes shown in Table 3.

\begin{tabular}{|c|c|c|c|c|c|c|}
\hline \multicolumn{7}{|c|}{ Table 4: Optimal Policy Rules for Model B } \\
\hline Regime & $\beta$ & $\mathrm{y}_{\mathrm{t}-1}$ & $\pi_{\mathrm{t}-1}$ & $\mathrm{q}_{\mathrm{t}-1}$ & $\mathrm{y}_{\mathrm{t}-1}^{\mathrm{f}}$ & $\pi_{\mathrm{t}-1}^{\mathrm{f}}$ \\
\hline $\operatorname{FIT}\left(\pi_{\mathrm{t}}\right)$ & 0.5 & 2.185 & 0.851 & 0.716 & -0.432 & -0.221 \\
$\operatorname{SIT}\left(\pi_{\mathrm{t}}\right)$ & 1.0 & 2.796 & 1.683 & 0.710 & -0.431 & -0.220 \\
$\operatorname{FIT}\left(\pi_{\mathrm{t}}^{\mathrm{c}}\right)$ & 0.5 & 1.954 & 0.770 & 0.595 & -0.257 & -0.145 \\
$\operatorname{SIT}\left(\pi_{\mathrm{t}}^{\mathrm{c}}\right)$ & 1.0 & 1.707 & 0.898 & 0.348 & 0.062 & -0.025 \\
\hline
\end{tabular}

Of special interest is the fact that with forward-looking agents domestic monetary policy now optimally responds negatively to the foreign output gap and foreign inflation (excluding $\operatorname{SIT}\left(\pi_{t}^{c}\right)$ where policy tightens in response to $\left.\mathrm{y}_{\mathrm{t}-1}^{\mathrm{f}}\right)$. In Table 2 the feedback coefficients applied to $\mathrm{y}_{\mathrm{t}-1}^{\mathrm{f}}$ and $\pi_{\mathrm{t}-1}^{\mathrm{f}}$ were positive across all policy regimes considered. The intuition behind these negative feedback coefficients is unclear, but is likely to involve the interaction between domestic and foreign monetary policies. The foreign monetary authority raises interest rates in response to both $\mathrm{y}_{\mathrm{t}-1}^{\mathrm{f}}$ and $\pi_{\mathrm{t}-1}^{\mathrm{f}}$. The higher foreign interest rate causes capital to flow from the domestic to the foreign economy inducing the exchange rate to depreciate. Consequently, movements in the foreign output gap and foreign inflation always occur in conjunction with movements to the real exchange rate. Table 4 shows that domestic monetary policy responds more aggressively to the real exchange rate when agents are forward-looking, which may in part explain the negative feedback coefficients in columns six and seven of Table 4.

Observe also that as monetary policy places greater weight on stabilizing inflation's variance, the feedback coefficient applied to $\mathrm{y}_{\mathrm{t}-1}$ rises under nontradeables inflation targeting, but falls under consumer price inflation targeting. This feature is also present in Table 2. Under nontradeables inflation targeting a more aggressive response to the domestic output gap serves to dampen future inflationary pressures. When consumer 
price inflation is being targeted such a strong response to the domestic output gap creates large swings in the domestic interest rate and the exchange rate. Volatility in the exchange rate adds directly to volatility in tradeables inflation, raising the variance of consumer price inflation. Because variability of consumer price inflation is to be avoided the response of policy makers is to lower to feedback coefficient applied to $\mathrm{y}_{\mathrm{t}-1}$ in the optimal policy reaction function.

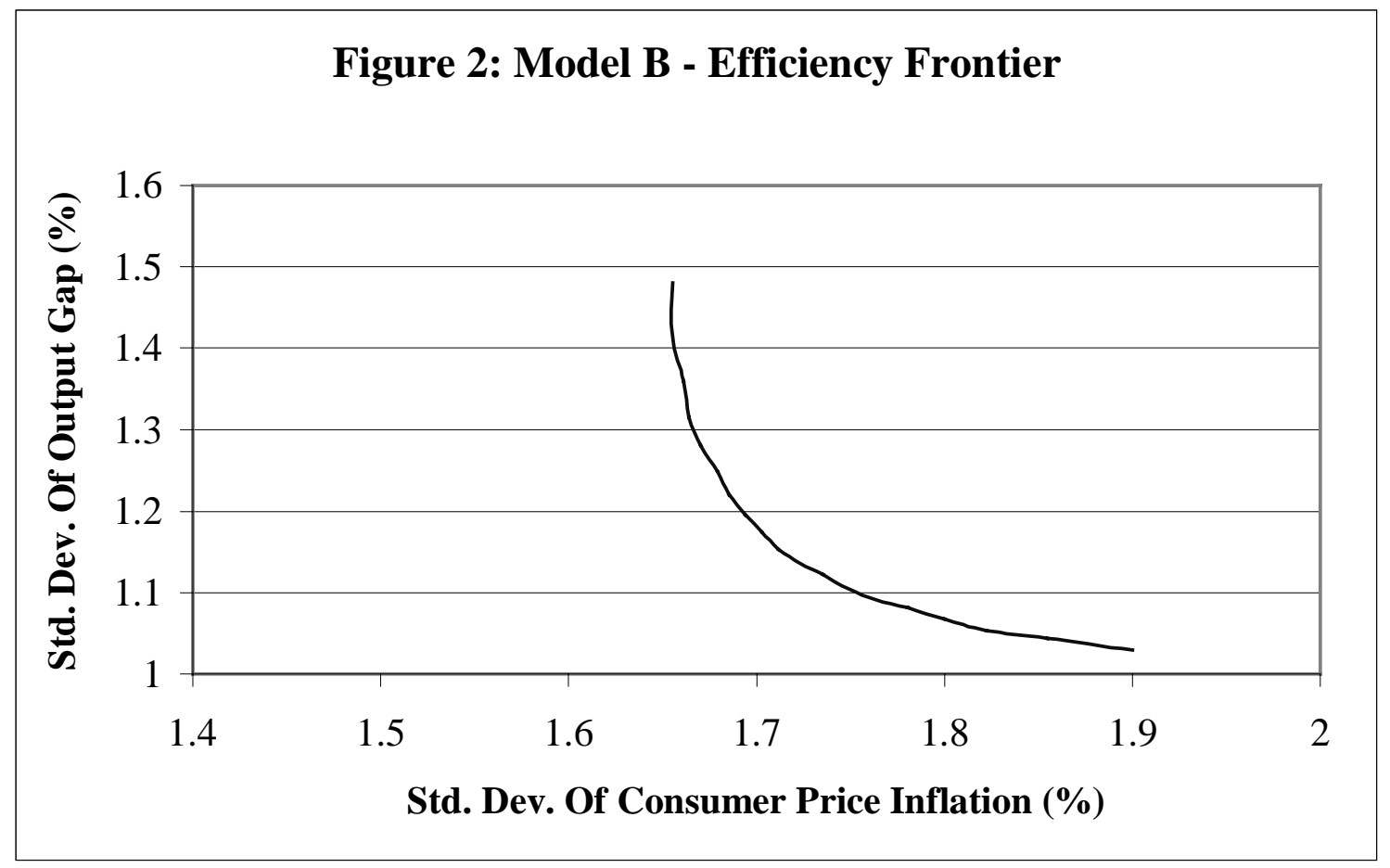

The efficiency frontier for Model B is plotted in Figure 2. Given the unconditional variances shown in Table 3 it is no surprise that the efficiency frontier for Model B lies closer to the origin than that for Model A.

\section{4) Optimal Simple Rules}

Having presented simulation results for optimal state-contingent rules in section 3, this section turns to optimal simple rules and their relative efficiency and stabilizing properties. Optimal simple rules are rules that optimize the policy maker's objective 
function conditional on a restricted state variable set; they use a sub-optimal information set to set policy. By construction, for the same policy preferences, optimal simple rules perform worse than optimal state-contingent rules. Nevertheless, it is useful to examine optimal simple rules in order to uncover those variables that are fundamental to the optimal state-contingent rule's performance. Knowing which variables underpin the optimal state-contingent rule's performance is important for developing simple rules that perform well. ${ }^{10}$

By way of motivation, consider Model A under the nontradeable inflation targeting regimes (Table 1). The coefficients on the two foreign variables: $\mathrm{y}_{\mathrm{t}-1}^{\mathrm{f}}$ and $\pi_{\mathrm{t}-1}^{\mathrm{f}}$ are each either zero or very close to zero. While the volatility in the variables themselves is important, removing these two foreign variables from the set of state variables forming domestic policy is unlikely to drastically undermine domestic policy performance. Effectively one might expect the four variables: $\mathrm{y}_{\mathrm{t}-1} ; \pi_{\mathrm{t}-1} ; \pi_{\mathrm{t}-1}^{\mathrm{c}}$; and $\mathrm{q}_{\mathrm{t}-1}$ to adequately approximate the state of the domestic economy for policy purposes. As shown below this is indeed the case.

In this section five simple rules are considered in both Models A and B. These five rules are:

$\mathrm{i}_{\mathrm{t}}=\varphi_{1} \mathrm{y}_{\mathrm{t}-1}+\varphi_{2} \pi_{\mathrm{t}-1}+\varphi_{3} \pi_{\mathrm{t}-1}^{\mathrm{c}}+\varphi_{4} \mathrm{q}_{\mathrm{t}-1}$

$\mathrm{i}_{\mathrm{t}}=\varphi_{1} \mathrm{y}_{\mathrm{t}-1}+\varphi_{2} \pi_{\mathrm{t}-1}+\varphi_{4} \mathrm{q}_{\mathrm{t}-1}$

$\mathrm{i}_{\mathrm{t}}=\varphi_{1} \mathrm{y}_{\mathrm{t}-1}+\varphi_{3} \pi_{\mathrm{t}-1}^{\mathrm{c}}+\varphi_{4} \mathrm{q}_{\mathrm{t}-1}$

$\mathrm{i}_{\mathrm{t}}=\varphi_{1} \mathrm{y}_{\mathrm{t}-1}+\varphi_{3} \pi_{\mathrm{t}-1}^{\mathrm{c}}$

$\mathrm{i}_{\mathrm{t}}=\varphi_{1} \mathrm{y}_{\mathrm{t}-1}+\varphi_{2} \pi_{\mathrm{t}-1}$.

(Rule 5)

\footnotetext{
${ }^{10}$ Cecchetti (1998) makes the observation that '...if the solution to the complex problem can be approximated by a simple rule, there may be substantial virtue in adopting the approximate solution.'
} 
Rules 2 and 3 are nested within rule 1, as are Rules 4 and 5, and all five simple rules exclude the two foreign variables $\mathrm{y}_{\mathrm{t}-1}^{\mathrm{f}}$ and $\pi_{\mathrm{t}-1}^{\mathrm{f}}$. In the case where $\varphi_{1}=0.5$ and $\varphi_{3}=1.5$ Rule 4 can be thought of as a Taylor rule (similarly when $\varphi_{1}=0.5$ and $\varphi_{2}=1.5$ in Rule 5). Alternatively, when $\varphi_{1}=\varphi_{3}$ (in Rule 4) and $\varphi_{1}=\varphi_{2}$ (in Rule 5) Rules 4 and 5 can be thought of as examples of Henderson and McKibbin (1993) rules. Rules 2 and 3 differ from Taylor type rules by including the level of the real exchange rate. Intuitively, adding the real exchange rate is a natural and potentially important extension for a small open economy model.

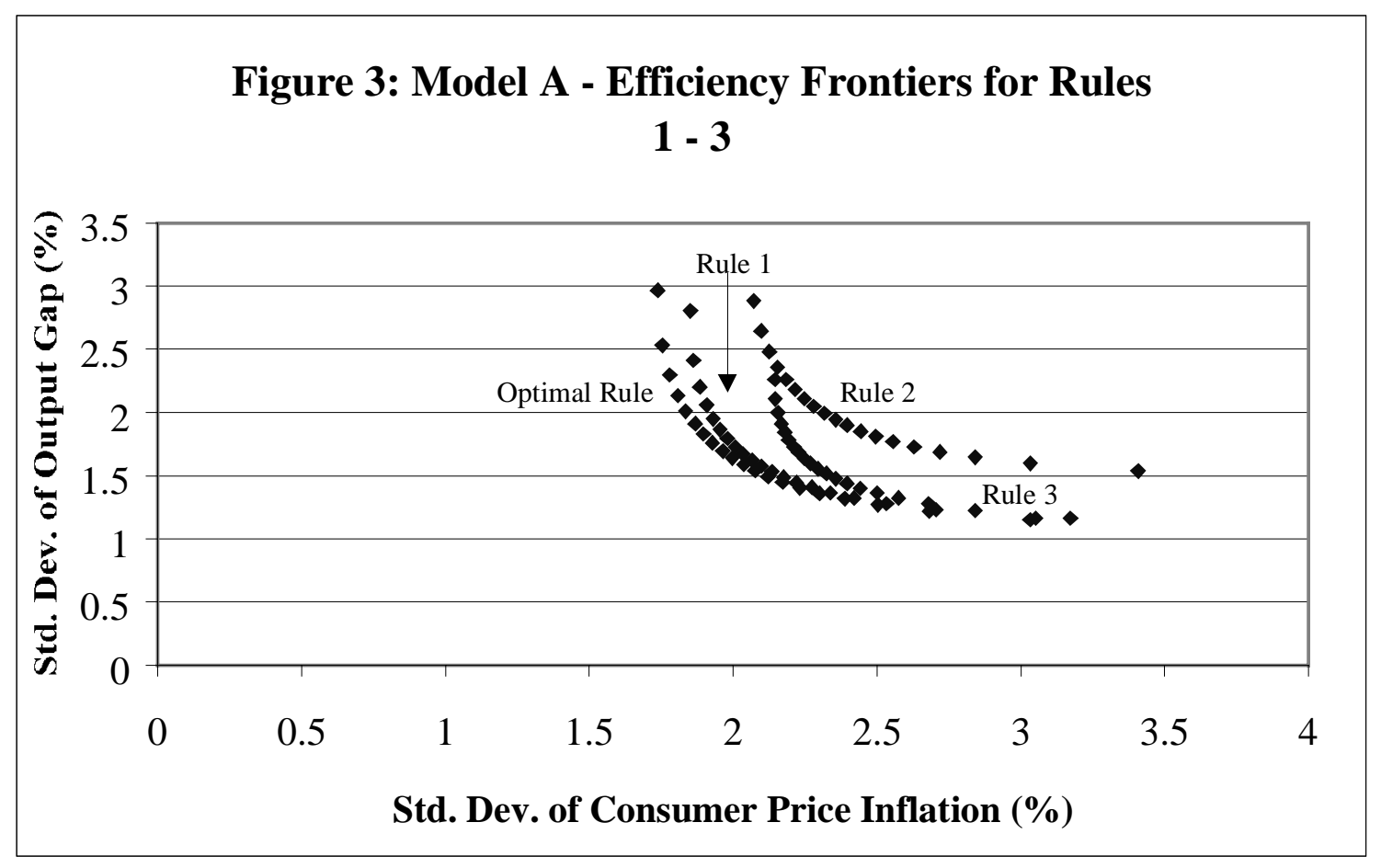

The results of this section can best be illustrated through efficiency frontiers. Figure 3 plots the efficiency frontiers for the optimal rule, Rule 1, Rule 2, and Rule 3 for Model A, assuming consumers' price inflation is targeted in the objective function. ${ }^{11}$ Analogous results for Model B are presented in Figure 5. Figure 4 compares Rules 4 and 5 with the optimal rule for Model A, while Figure 6 displays the same information for Model B.

\footnotetext{
${ }^{11}$ All of the efficiency frontiers that we present in this section have consumers' price inflation entering the policy objective function. None of our results or conclusions are materially affected by whether it is nontradeables' or consumers' price inflation that is targeted.
} 


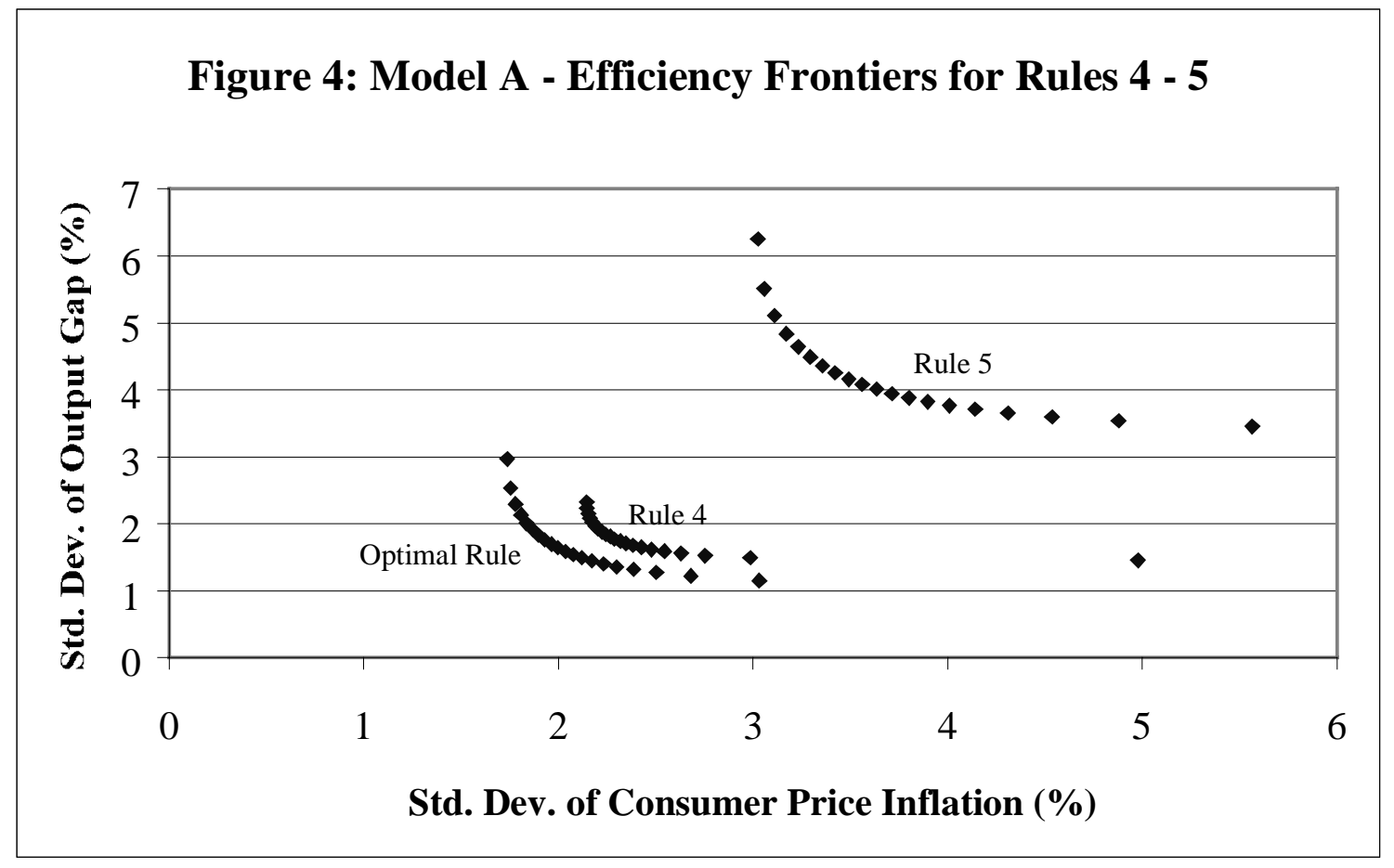

Beginning with Figure 3, the efficiency frontiers for the optimal rule and for Rule 1 are very similar to each other, only deviating when large weights are placed on consumers' price inflation in the objective function. From a practical standpoint very little is lost by excluding the two foreign variables $\mathrm{y}_{\mathrm{t}-1}^{\mathrm{f}}$ and $\pi_{\mathrm{t}-1}^{\mathrm{f}}$ from the rule, for moderate policy preferences. Rule 3 is superior to Rule 2 except, perhaps, in the extreme case of strict inflation targeting. Thus, conditional upon the output gap and the real exchange rate, consumer price inflation contains more useful information than nontradeables inflation regarding the state of the economy. This point is further underscored in Figure 4 where Rule 4 (which contains $\mathrm{y}_{\mathrm{t}-1}$ and $\pi_{\mathrm{t}-1}^{\mathrm{c}}$ ) is drastically superior to Rule 5 (which uses $\mathrm{y}_{\mathrm{t}-1}$ and $\left.\pi_{\mathrm{t}-1}\right)$. From Figures 3 and 4, together with Table 2, it appears that for Model A at least the three most important state variables for domestic policy are the output gap, consumer price inflation, and the real exchange rate. 


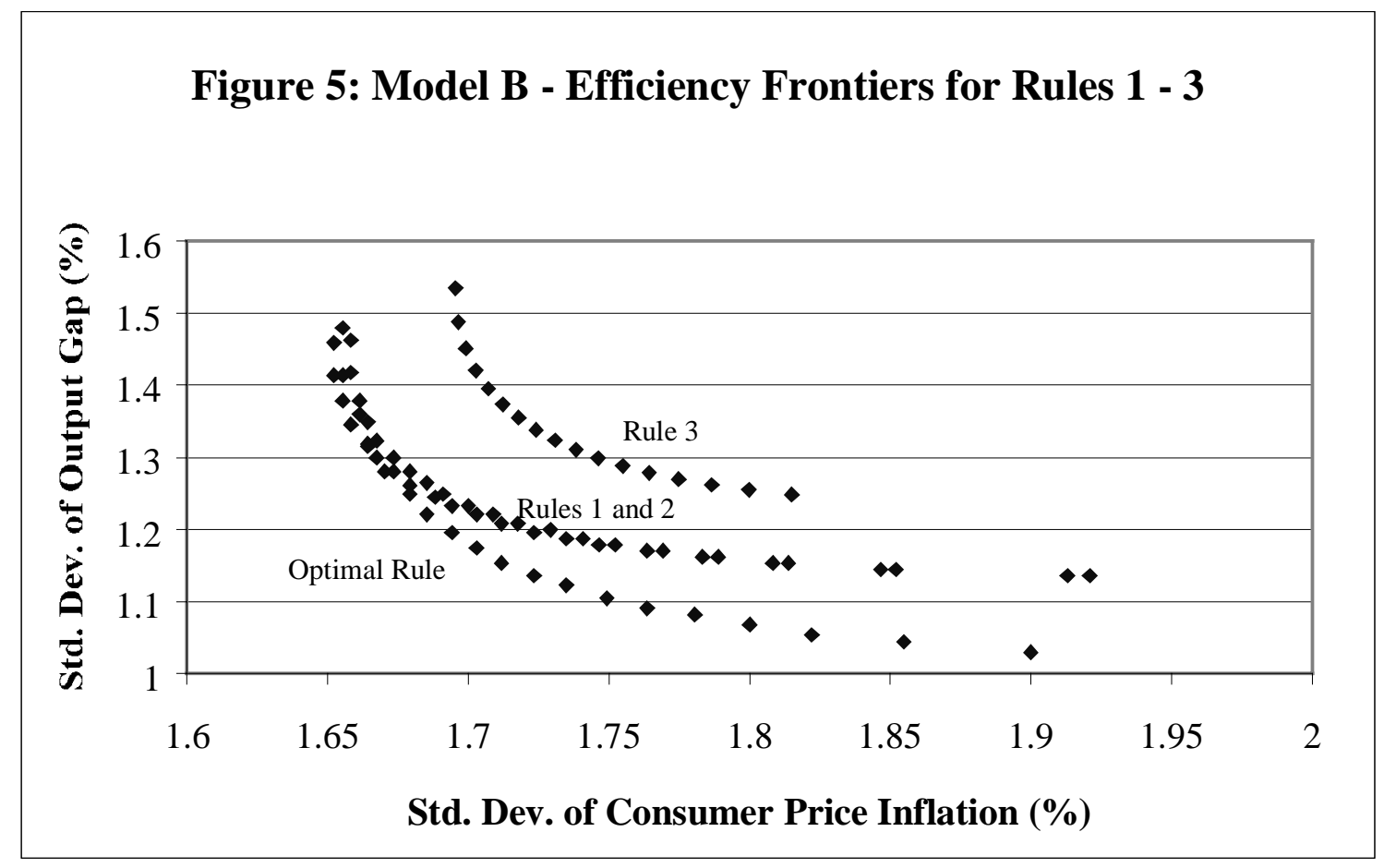

Figure 5 shows that in Model B information is lost when the foreign variables $\left(\mathrm{y}_{\mathrm{t}-1}^{\mathrm{f}}\right.$ and $\pi_{\mathrm{t}-1}^{\mathrm{f}}$ ) are excluded. Note that for Model B lagged consumer price inflation is not a state variable for the system: it provides no additional information about the state of the economy. When the two foreign variables are excluded, however, lagged consumer price inflation does become informative, but only marginally so. Rules 1 and 2, which only differ in that Rule 2 excludes $\pi_{\mathrm{t}-1}^{\mathrm{c}}$ perform nearly identically. The fact that Rule 3 performs worse than Rule 2 points to the superior information present in nontradeables inflation over consumer price inflation, which is the opposite of the result obtained for Model A. This result, of course, turns on how financial markets form their consumers' price inflation expectations. 


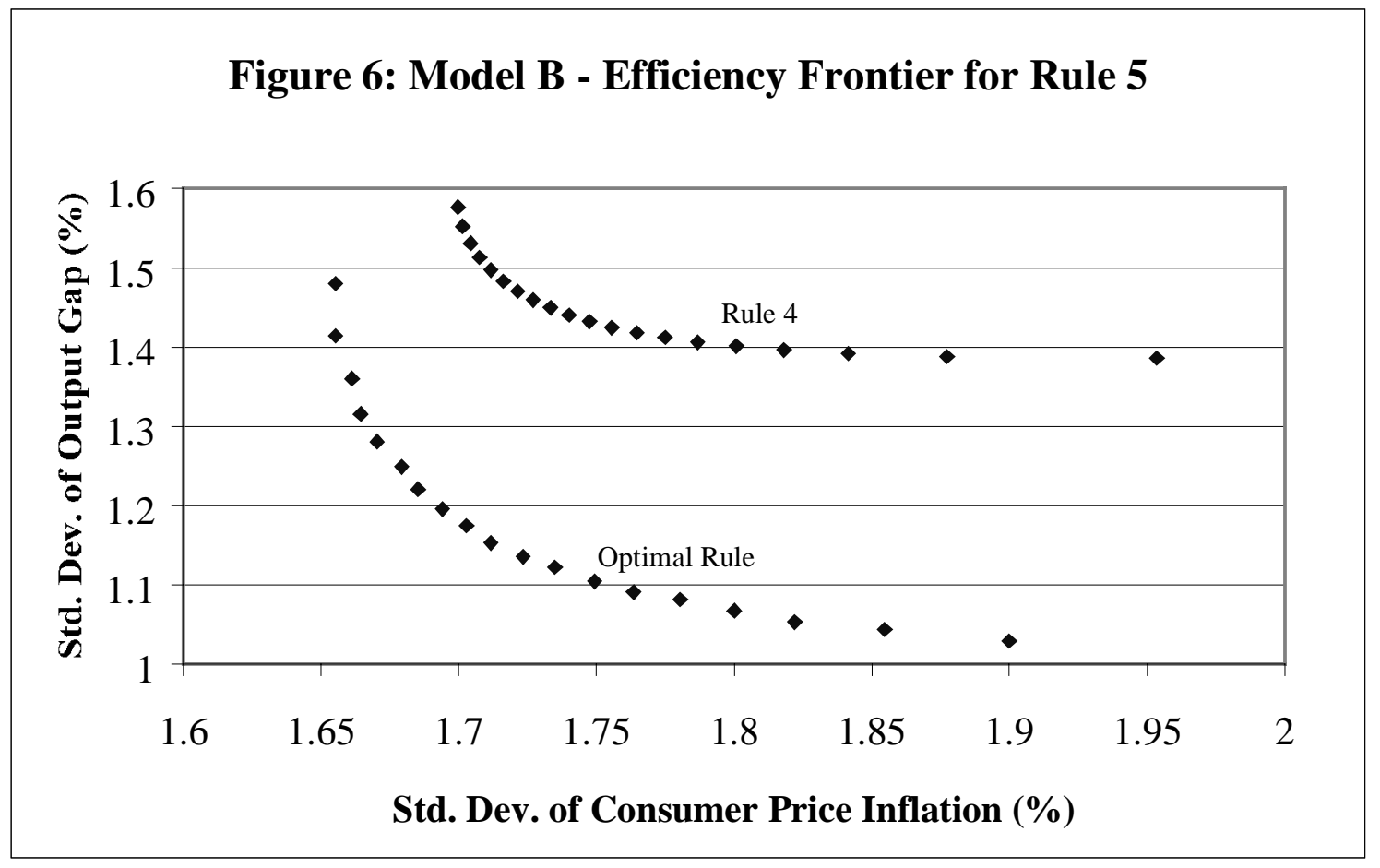

Figure 6 contrasts the performance of Rule 4 with that of the optimal state-contingent rule. $^{12}$ The deviations between these two efficiency frontiers are large highlighting the Taylor type rule's inefficiency. Rule 3, which augments Rule 4 with the real exchange rate, generates much lower variances for the output gap.

It is of interest to now look at whether any of the optimal simple rules generated by Rules 4 or 5 resemble either a Taylor rule or a Henderson and McKibbin rule. For this purpose we represent Taylor's rule as

$\mathrm{i}_{\mathrm{t}}=0.5 \mathrm{y}_{\mathrm{t}-1}+1.5 \pi_{\mathrm{t}-1}^{*}$,

(Taylor)

where $\pi_{t-1}^{*}$ may be either nontradeables inflation or consumer price inflation. Similarly we represent the Henderson and McKibbin rule as

${ }^{12}$ Results for Rule 5 are not shown because for that rule we were unable to find optimal parameters for which the solution to the rational expectations model was real valued. Binder and Pesaran (1995) and Uhlig (1999) show that a model's rational expectations solution must satisfy a matrix quadratic. As we moved toward optimal parameters in Rule 5 this matrix quadratic failed to have a real solution. 
$\mathrm{i}_{\mathrm{t}}=\chi\left[\mathrm{y}_{\mathrm{t}-1}+\pi_{\mathrm{t}-1}^{*}\right]$

Table 5 shows the optimal simple feedback rules for a number of policy regimes in both Models A and B. Throughout, the foreign policy regime is held constant with $\beta^{f}=0.5$.

\begin{tabular}{|c|c|c|c|c|}
\hline \multicolumn{5}{|c|}{$\begin{array}{r}\text { Table 5: Optimal Simple Rules for Model A. Targe } \\
\text { Consumer Price Inflation }\end{array}$} \\
\hline & $\beta$ & $\mathrm{y}_{\mathrm{t}-1}$ & $\pi_{\mathrm{t}-1}$ & $\pi_{\mathrm{t}-1}^{\mathrm{c}}$ \\
\hline \multirow[t]{3}{*}{ Rule four } & 0.25 & 1.720 & - & 1.588 \\
\hline & 0.50 & 1.585 & - & 1.723 \\
\hline & 0.75 & 1.455 & - & 1.830 \\
\hline \multirow[t]{3}{*}{ Rule five } & 0.25 & 1.892 & 1.208 & - \\
\hline & 0.50 & 1.721 & 1.271 & - \\
\hline & 0.75 & 1.499 & 1.311 & - \\
\hline \multicolumn{5}{|c|}{ Rule 4 for Model B. Targeting the Output Gap and Consumer Price Inflation } \\
\hline & $\beta$ & $\mathrm{y}_{\mathrm{t}-1}$ & $\pi_{\mathrm{t}-1}$ & $\pi_{\mathrm{t}-1}^{\mathrm{c}}$ \\
\hline \multirow[t]{3}{*}{ Rule four } & 0.25 & 2.245 & - & 0.793 \\
\hline & 0.50 & 2.140 & - & 0.829 \\
\hline & 0.75 & 2.016 & - & 0.859 \\
\hline
\end{tabular}

The feedback coefficient on the lagged output gap is much greater than 0.5 for all of the policy regimes considered in Table 5. The Taylor rule's coefficient of 1.5 on the lagged inflation term is, however, broadly right. If we were to set $\chi=1.6$ (roughly), then a Henderson and McKibbin rule would approximate reasonably well the simulation results for Rule 4.

Model B tells a similar story. The feedback coefficient on the output gap for the Taylor rule needs to be raised considerably if it is to be interpreted as an optimal simple rule. But with $\chi=1.7$ (or so) a Henderson and McKibbin rule is not dissimilar to the optimal simple rule, Rule $4 .^{13}$

\footnotetext{
${ }^{13}$ While it is interesting that a Henderson and McKibbin rule based on the lagged output gap and lagged consumer price inflation can be viewed (loosely) as an optimal simple rule for Model A, it
} 


\section{5) Conclusions}

This paper developed and analyzed the performance of a number of optimal simple rules. These simple rules were developed using optimization methods in the context of a stylized small open economy model. To construct these simple rules we first solved for the optimal state-contingent policy reaction function as a feedback equation dependent on the economy's pre-determined variables. Solving for the optimal state-contingent policy rule is useful for two reasons. First it provides an important benchmark against which to compare the performance of subsequently developed optimal simple rules. Second it provides information about which state variables are important to the performance of the optimal state-contingent rule, and those that are of lesser significance. In the forwardlooking version of the model we solved for the optimal pre-commitment state-contingent rule and used that as the benchmark.

Having solved for the optimal state-contingent policy reaction function we successively removed state variables from the optimal rule and assessed the importance of each state variable by how its removal affected the economy's efficiency frontier. In this analysis the efficiency frontier acted as a visual representation of the evaluated policy objective function. One objective of this process was to develop high performing simple rules, simple rules whose performance is an acceptable approximation to that of the optimal state-contingent rule. Again, for the version of the model with forward-looking rational expectations, we solved for optimal simple pre-commitment rules. A second objective of

this process was to investigate whether Taylor type rules, which exclude measures of external competitiveness, are likely to perform well in small open economies.

Addressing the latter question first, our results indicate that simple Taylor type rules based on just the output gap and annual inflation do not perform well in small open economies. Where the choice is between a Taylor type rule based on domestic inflation

is not too surprising that the Taylor rule cannot. The Taylor rule imposes two restrictions upon the feedback coefficients in the conditional rule while the Henderson and McKibbin rule only imposes one. Thus for the Henderson and McKibbin rule we have a degree of freedom with which to fit the rule to the model. 
and one based on consumer price inflation, that containing consumer price inflation is superior, regardless of whether it is consumer price inflation or domestic inflation that enters the policy objective function. We suggest that it is the tradeable goods component included in consumers' price inflation, but not in domestic inflation, that leads to Taylor type rules based on consumers' price inflation outperforming those based on domestic inflation.

For the former question, we find that simple rules that include the real exchange rate as a measure of external competitiveness in addition to the output gap and inflation tend to perform much better than Taylor type rules, their performance being more reflective of the optimal state-contingent rule. Including an external competitiveness variable like the real exchange rate appears essential to the performance of the optimal state-contingent rule and consequently any high performing simple rule must also include such a variable. The importance of the real exchange rate for policy in small open economies bolsters our finding that Taylor type rules containing consumers price inflation work better than those containing domestic inflation. 


\section{References}

Ahn, C-M, (2000), 'The Monetary Policy rule in Australia: Inflation Targeting and Policy Reaction', Australian National University, Working Paper in Trade and Development \#00/07.

Ball, L., (1999a), 'Efficient Rules for Monetary Policy', International Finance, 2, 1, pp63-83.

Ball, L., (1999b), 'Policy Rules for Open Economies', in Taylor, J., (ed) Monetary Policy Rules, Chicago University Press.

Barro, R., and D. Gordon, (1983), 'Rules, Discretion and Reputation in a Model of Monetary Policy', Journal of Monetary Economics, 12, pp101-121.

Beechey, M., Bharucha, N., Cagliarini, A., Gruen, D., and C. Thompson, (2000), 'A Small Model of The Australian Economy', Reserve Bank of Australia, Research Discussion Paper \#2000-05.

Binder, M., and H. Pesaran, (1995), 'Multivariate Rational Expectations Models and Macroeconomic Modeling: A Review and Some New Results', in Pesaran, H. and M. Wickens (eds), Handbook of Applied Econometrics.

Buiter, W., and M. Miller, (1981), 'Monetary Policy and International Competitiveness: The Problems of Adjustment', Oxford Economic Papers, 33, pp143-175.

Cecchetti, S., (1998), 'Central bank Policy Rules: Conceptual Issues and Practical Considerations', in Wagner, H. (ed), Current Issues in Monetary Economics, Physica-Verlag, Heidelberg.

Clarida, R., Gali, J., and M. Gertler, (1998), 'Monetary Policy Rules in Practice: Some International Evidence', European Economic Review, 42, pp1033-1067.

Dennis, R., (2000), 'Solving for Optimal Simple Rules in Rational Expectations Models', Federal Reserve Bank of San Francisco Working Paper, \#2000-10.

Dornbusch, R., (1976), 'Expectations and Exchange Rate Dynamics', Journal of Political Economy, 84, 6, pp1161-1176.

Duguay, P., (1994), 'Empirical Evidence on the Strength of the Monetary Transmission Mechanism in Canada', Journal of Monetary Economics, 33, pp39-61.

Eika, K., Ericsson, N., and R. Nymoen, (1996), "Hazards in Implementing a Monetary Conditions Index', Oxford Bulletin of Economics and Statistics, 58, 4, pp765-790. 
Fair, R., and E. Howrey, (1996), 'Evaluating Alternative Monetary Policy Rules', Journal of Monetary Economics, 38, 2, pp173-193.

Fuhrer, J., and G. Moore, (1995), 'Inflation Persistence', Quarterly Journal of Economics, 110, 1, pp127-159.

Gerlach, S., and G. Schnabel, (1999), 'The Taylor Rule and Interest Rates in the EMU Area: A Note', Bank for International Settlements, Working Paper \#73.

Gerlach, S., and F. Smets, (2001), 'MCIs and Monetary Policy in Small Open Economies Under Floating Exchange Rates', European Economic Review, forthcoming

Henderson, D., and W. McKibbin (1993), 'A Comparison of some Basic Monetary Policy Regimes for Open Economies', Carnegie-Rochester Series on Public Policy, 39, pp221-317.

McCallum, B., (1999), 'Issues in the Design of Monetary Policy Rules' in Taylor, J and M. Woodford (eds), Handbook of Macroeconomics, North Holland.

Nelson, E., (2000), 'UK Monetary Policy 1972 -1997: A Guide using Taylor's Rule', Bank of England, Mimeo.

Orphanides, A., (1997), 'Monetary Policy Rules Based on Real-Time Data', Board of Governors of the Federal Reserve System, Working Paper.

Pagan, A., (1997), 'Whatever Happened to Optimal Control of Econometric Models?', Control Engineering Practice, 5, pp527-533.

Rudebusch, G., and L. Svensson, (1999), 'Policy Rules for Inflation Targeting', in Taylor, J. (ed) Monetary Policy Rules, Chicago University Press.

Shanchez-Fung, J., (2000), 'Estimating a Taylor Type Monetary Policy Reaction Function for the Case of a Small Developing Economy', University of Kent at Canterbury, Mimeo.

Svensson, L., (1997), 'Inflation Forecast Targeting: Implementing and Monitoring Inflation Targets', European Economic Review, 41, pp1111-1146.

Svensson, L., (1998), 'Open-Economy Inflation Targeting', Journal of International Economics, 50, 1, pp155-183.

Taylor, J., (1980), 'Aggregate Dynamics and Staggered Contracts', Journal of Political Economy, 88, 1, pp1-23.

Taylor, J., (1993), 'Discretion Versus Policy Rules in Practice', Carnegie-Rochester Conference Series on Public Policy, 39, pp195-214. 
Taylor, J., (1999), 'The Robustness and Efficiency of Monetary Policy Rules as Guidelines for Interest Rate Setting by the European Central Bank', Journal of Monetary Economics, 43, 3, pp655-679.

Uhlig, H., (1999), 'A Toolkit for Analysing Nonlinear Dynamic Stochastic Models Easily', in Marimon, R., and A. Scott (eds) Computational Methods for the Study of Dynamic Economies, Oxford University Press, New York, pp30-61.

Walsh, C., (1995), 'Optimal Contracts for Central Bankers', The American Economic Review, March. 